\title{
RESEPSI ANAK USIA SMP TERHADAP NOVEL TEENLIT YANG BERJUDUL DALAM RINAI HUJAN KARYA ARIE SAPTADJI
}

\author{
Luluk Diana Novita Sari \\ Program Studi Pendidikan Bahasa dan Sastra Indonesia \\ Fakultas Keguruan dan Ilmu Pendidikan \\ dianaluluk@ rocketmail.com
}

\begin{abstract}
Abstrak
Sastra adalah karya cipta atau fiksi yang bersifat imajinatif dengan menggunakan bahasa yang indah. Sastra menjadi dua jenis, yakni sastra literer dan sastra populer atau sastra "serius" dan "hiburan". Salah satu bentuk sastra adalah novel. Salah satu jenis novel adalah teenlit. Teenlit adalah kisah seputar remaja, mengenai kisah percintaanya, romantisnya, kehidupannya, khayalannya, impiannya, dan lingkup remaja ini sendiri dari remaja SMP sampai mahasiswa. Tujuan penelitian ini adalah untuk mendeskripsikan resepsi anak usia SMP tentang nilai estetika, muatan emosional, dan nilai didaktis dalam novel teenlit yang berjudul Dalam Rinai Hujan karya Arie Saptadji.Penelitian ini menggunakan pendekatan resepsi sastra, sesuai dengan namanya pendekatan ini mencoba memahami dan menilai karya sastra berdasarkan tanggapan para pembaca karya sastra tersebut. Penelitian resepsi pembaca terhadap novel teenlit yang berjudul Dalam Rinai Hujan ini menggunakan metode deskriptif kualitatif yakni penelitian yang menghasilkan prosedur analisis dan tidak menggunakan prosedur analisis statistik atau cara kuantifikasi lainya. Penelitian ini penelitian yang bermaksud untuk memahami fenomena tentang apa yang dialami oleh subjek penelitian misalnya perilaku, resepsi, motivasi, dan lainlain. Sumber data dalam penelitian ini adalah anak usia SMP di Desa Tumpakrejo Kecamatan Gedangan yang terdiri dari laki-laki dan perempuan dengan jumlah sebanyak 34 orang.
\end{abstract}

Kata Kunci: resepsi, novel, novel teenlit

\begin{abstract}
Literary works are the products of imaginative fiction using figurative languages. Literature is divided into two based on the purposes: pure literature (serious) and popular literature (entertainment). One of the produtcs of popular culture is novels. Teenlit is one of the novels focusing on the romantic stories of the students of yunior high schools up to university levels. This study aimed at describing yunior high school students' receptions towards esthetic, emotional, and deductif values found in the novel Teenlit entitled Dalam Rinai Hujan written by Arie Saptadji. This study employed literary reception approach intended to understand the phenomena experienced by the subjects of the study such as behaviors, receptions, motivation, etc. The sources of data was taken from 34 female and male yunior high school students at Tumpakrejo village, Gedangan regency, Malang.
\end{abstract}

Keywords:: reception, novel, novel teenlit 


\section{PENDAHULUAN}

Sastra adalah karya cipta atau fiksi yang bersifat imajinatif dengan menggunakan bahasa yang indah.

Dunia kesusastraan mengenal prosa sebagai salah satu genre di samping genre-genre lainnya. Prosa dalam kesusastraan juga disebut fiksi.

Sumardjo (1982:45-48) dan Nurgiyantoro (2002:16-22) membagi sastra menjadi dua jenis, yakni sastra literer dan sastra populer atau sastra "serius" dan "hiburan".

Sastra literer adalah sastra yang memiliki bobot literer dan berisi masalah-masalah serius dalam kehidupan manusia, seperti masalah kemanusiaan, politik, moral, agama, sufistik, filsafat, dan sebagainya. Selain itu, pada umumnya sastra literer memiliki fungsi sosial, yaitu memperkaya khasanah batin pembaca atau penikmatnya. Adapun sastra populer adalah sastra yang ringan bobot literernya, dan berisi masalah-masalah yang lebih mengedepankan hiburan belaka. Pada umumnya, sastra populer mengemukakan kenyataan semu, bahkan fantasi atau cerita yang mengandung kadar emosi berlebihan.

Novel menurut kamus besar bahasa indonesia adalah karangan prosa yang panjang mengandung rangkaian cerita kehidupan seorang dengan orang disekelilingnya dengan menonjolkan watak dan sifat setiap pelakunya. Novel merupakan bentuk karya sastra yang didalamnya terdapat nilai-nilai sosial budaya, moral, dan pendidikan. Awalnya, novel populer dianggap tidak penting dan tidak bermanfaat bagi perkembangan penulisan sastra, namun dalam perkembangannya novel populer mampu menunjukkan fungsi dan manfaatnya bagi perkembangan penulisan sastra. Kata populer yang identik dengan merakyat dianggap rendah, tidak indah, dan bahkan salah. Menurut Teeuw (1989:169170), ada sejumlah alasan mengapa sastra hiburan tidak selayaknya dikesampingkan dari perbincangan sastra Indonesia modern. Novel hiburan merupakan bagian terbesar dari seluruh jumlah novel yang ada.

Pada zaman sekarang kegemaran siswa untuk menggemari karya sastra semakin menurun, siswa lebih gemar membaca teenlit dibandingkan dengan karya sastra jenis serius kenyataan ini mendorong penulis untuk meneliti apa sesungguhnya minat, tujuan dan manfaat siswa membaca teenlit.

Teenlit singkatan dari teenager literature (sastra remaja). Teenlit adalah kisah seputar remaja, mengenai kisah percintaanya, romantisnya, kehidupannya, khayalannya, impiannya, dan lingkup remaja ini sendiri dari remaja SMP sampai mahasiswa. Novel populer jenis teenlit merupakan novel hiburan karena bentuk cerita yang ringan dan tidak menampilkan pemikiran yang berat, namun akan tetap digemari oleh remaja 
Masa-masa remaja adalah tahap peralihan dari masa anak-anak menuju masa dewasa, sehingga dalam perjalanannya anak-anak pada masa ini mudah terpengaruh oleh hal-hal disekitarnya atau hal-hal yang sering mereka lakukan dalam hal ini membaca bacaan teenlit yang didalamnya banyak terdapat cerita mengenai kehidupan remaja dalam pandangan menulis cerita. Hal ini akan membawakan berbagai macam dampak yang berbeda pada tiap individunya. Dengan dasar ini penulis melakukan penelitian dengan mengangkat judul "Resepsi Anak Usia SMP Terhadap Novel Teenlit yang berjudul Dalam Rinai Hujan Karya Arie Saptadji”. Mengingat ada banyak pelajaran positif dan nilai-nilai pendidikan yang dapat dicontoh dan diterapkan di dunia nyata oleh pembaca yang khususnya adalah remaja.

Secara umum, rumusan masalah penelitian ini yakni bagaimana resepsi siswa usia SMP terhadap novel teenlit yang berjudul Dalam Rinai Hujan karya Arie Saptadji.

Berdasarkan latar belakang yang dipaparkan di atas, rumusan masalah khusus penelitian ini adalah sebagai berikut :

a) Bagaimana resepsi anak usia SMP tentang nilai Estetika novel teenlit yang berjudul Dalam Rinai Hujan karya Arie Saptadji?

b) Bagaimana resepsi anak usia SMP tentang muatan emosional dalam novel teenliit yang berjudul Dalam Rinai Hujan karya Arie Saptadji ?

c) Bagaimana resepsi anak usia SMP tentang nilai didaktis dalam novel teenlit yang berjudul Dalam Rinai Hujan karya Arie Saptadji?

Secara umum penelitian ini bertujuan mendeskripsikan resepsi anak usia SMP terhadap novel teenlit yang berjudul Dalam Rinai Hujan karya Arie Saptadji.

Sesuai dengan rumusan masalah yang telah dipaparkan di atas, tujuan khusus dari penelitian ini adalah :

a) Mendeskripsikan resepsi anak usia SMP tentang nilai estetika novel teenlit yang berjudul Dalam Rinai Hujan karya Arie Saptadji.

b) Mendeskripsikan resepsi anak usia SMP tentang muatan emosional dalam novel teenlit yang berjudul Dalam Rinai Hujankarya Arie Saptadji.

c) Mendeskrisikan resepsi anak usia SMP tentang nilai didaktis dalam novel teenlit yang berjudul Dalam Rinai Hujan karya Arie Saptadji.

\section{METODE}

Penelitian ini menggunakan pendekatan resepsi sastra, sesuai dengan namanya pendekatan ini mencoba memahami dan menilai karya sastra berdasarkan tanggapan para pembaca karya sastra tersebut. Seorang dengan orang lain akan berbeda dalam menanggapi karya sastra, tiap pembaca mempunyai wujud karya sastra sebelum ia membaca sebuah 
karya sastra. Dalam arti seorang pembaca itu mempunyai konsep atau pengertian tertentu mengenai sebuah karya sastra, baik sajak, cerpen, maupun novel.

Menurut pradopo (2013 : 208) karya sastra itu merupakan penjelmaan ekspresi yang padat, maka ada hal-hal yang kecil-kecil tak disebutkan, begitu juga hal-hal yang tak langsung berhubungan dengan cerita atau masalah. Dengan demikian hal, setiap pembaca diharapkan mengisi kekosongan tersebut.

Penelitian resepsi pembaca terhadap novel teenlit yang berjudul Dalam Rinai Hujan ini menggunakan metode deskriptif kualitatif yakni penelitian yang menghasilkan prosedur analisis dan tidak menggunakan prosedur analisis statistik atau cara kuantifikasi lainya. Metode deskriptif kualitatif memberikan perhatian terhadap data alamiah, data dalam hubungannya dengan konteks keberadaannya. Subjek penelitian dalam penelitian ini adalah anak usia SMP di Desa Tumpakrejo Kecamatan Gedangan Malang yang berjumlah 34 orang. Sebagai anak SMP mereka juga sudah mengenal tentang novel. Data diperoleh dari sumber yang disebut sumber data. Sumber data dalam penelitian ini adalah anak usia SMP di Desa Tumpakrejo Kecamatan Gedangan yang terdiri dari laki-laki dan perempuan. . Instrumen dalam penelitian ini dalam bentuk kuesioner yang disebarkan kepada anak usia SMP di Desa Tumpakrejo Kecamatan Gedagan yang berisi pertanyaan tentang bagaimana resepsi anak usia SMP terhadap novel teenlit yang berjudul Dalam Rinai Hujan. Untuk mendapatkan data yang lebih akurat maka penelitian ini menggunakan teknik tertentu yaitu pengumpulan data, validasi dan analisis data. Setelah data terkumpul kemudian dilanjutkan dengan analisis data. Proses analisis data penelitian ini melalui tahap berikut: pengecekan, penyelesaian, penilaian. Prosedur penelitian ini terdiri atas 3 tahap yaitu: (1) tahap persiapan, (2) tahap pelaksanaan, (3) dan tahap penyelesaian. Pada tahap pelaksanaan penelitian ini, kegiatan yang akan dilakukan oleh peneliti meliputi: (1) pengumpulan data melalui wawancara, (2) mengolah data, (3) penyajian data.

\section{PEMBAHASAN}

a) Nilai- Nilai Estetika.

Istilah estetika (aest hetics) berasal dari bahasa yunani, aisthesis yang berarti pencerapan indra' (sense perception) atau aisthetika yang artinya sesuatu yang dapat diserap oleh panca indra. Estetika sendiri juga disebuit sebagai "filsafat keindahan" (philosophy of beauty).

Estetika repsepsi ini dimaksudkan bagaimana pembaca memberikan makna terhadap karya sastra sehingga dapat memberikan tanggapan terhadapnya. Tanggapan tersebut berupa pembaca dapat memahami karya itu atau dapat melihat hakikat estetikanya. Dalam novel Dalam Rinai Hujan memiliki bagian-bagian cerita yang dibuat sedemikian rupa sehingga 
membentuk alur cerita yang dapat ditelusuri urutan waktunya. Novel Dalam Rinai Hujan merupakan novel popular yang berisi cerita yang ringan dan sesuai bila dibaca untuk anak seusia SMP. Sehingga tidak ada kesulitan untuk mereka dalam meresepsi unsur estetika dalam novel Dalam Rinai Hujan.

Namun pada kenyataannya ada hal yang berbeda, dari hasil quesioner yang peneliti berikan kepada responden, terdapat hasil yang berbeda pula. Dari hasil quesioner terdapat enam belas anak yang salah dalam menjawab pertanyaan tentang tema. Hal ini menunjukkan bahwa hampir lima puluh persen dari responden belum menguasai apa yang dimaksud dengan tema. Pengetahuan mereka tentang tema dengan merealisasikan dalam memberikan tanggapannya tidak sesuai. Nampak kebingungan dan keraguan mereka dalam menjawab, mana yang berupa ide pokok dan mana yang memang inti atau topik cerita. Untuk alur terdapat dua jawaban salah semua dan tujuh jawaban salah satu dalam menjawabnya. Dalam hal ini dapat disimpulkan sebagian besar responden telah menguasai dan memahami apa yang dimaksud dengan alur, walaupun hanya beberapa responden saja yang menjawab salah. Dari hasil quesioner terdapat tiga puluh empat responden yang menjawab benar pertanyaan tentang tokoh. Dalam hal ini tidak diragukan lagi pengetahuan responden tentang tokoh, karena mereka dapat merealisasikan dalam jawaban benar mereka. Untuk latar terdapat empat jawaban salah dalam menjawabnya. Hal ini menunjukkan bahwa tidak ada masalah dalam responden menjawab tentang latar. Hanya dua belas persen saja yang tidak memahami dan mengetahui tentang latar. Yang terakhir terdapat tiga puluh yang menjawab salah pertanyaan tentang sudut pandang. Delapan pulu delapan persen anak seusia SMP mengalami kebingungan dan kerancuan dalam menjawab tentang sudut pandang ini. Kurangnya pemahaman mereka dalam memaknai pengertian dari sudut pandang sendiri menjadi salah satu faktor penyebab salahnya mereka dalam menjawab pertanyaan.

Dari pembahasan di atas dapat disimpulkan bahwa sebagian besar yaitu lima puluh dua persen responden dapat menjawab semua pertanyaan tentang estetika novel Dalam Rinai Hujan. Yang berarti sebagian besar responden menjawab delapan soal benar, yaitu tiga puluh empat responden menjawab benar soal nomor 1, tiga puluh empat responden menjawab benar soal nomor 3, tiga puluh empat responden menjawab benar soal nomor 4, dua puluh delapan responden menjawab benar soal nomor 5, dua puluh delapan responden menjawab benar soal nomor 6 , tiga puluh tiga responden menjawab benar soal nomor 7 , tiga puluh responden menjawab benar soal nomor 8 , dan tiga puluh satu responden menjawab benar soal nomor 10. Hal ini menunjukkan bahwa tidak ada masalah untuk memahami nilai-nilai estetika dalam novel, walaupun ada sebagian responden yang kurang memahami beberapa unsur dalam nilai-nilai estetika. 
b) Nilai-nilai Emosional.

Kata emosi berasal dari bahasa latin, yaitu emovere, yang berarti bergerak menjauh. Arti kata ini menyiratkan bahwa kecenderungan bertindak merupakan hal mutlak dalam emosi. Emosi pada dasarnya adalah dorongan untuk bertindak. Biasanya emosi merupakan reaksi terhadap rangsangan dari luar dan dalam diri individu. Sebagai contoh emosi gembira mendorong perubahan suasana hati seseorang, sehingga secara fisiologi terlihat tertawa, emosi sedih mendorong seseorang berperilaku menangis. Dari hasil quesioner yang didapatkan peneliti terdapat hasil yang menunjukkan bahwa responden masih kurang bisa membedakan perasaan mana yang termasuk dalam amarah, kesedihan, kenikmatan/kesenangan, terkejut, dan ketakutan,Hal ini dapat dilihat uraian berikut, untuk pertanyaan tentang amarah yang berupa kekecawaan terdapat empat jawaban salah, kemarahan terdapat dua jawaban salah, dan kebencian terdapat tiga puluh tiga jawaban salah dari responden. Sebagian besar responden ini kurang tahu dan memahami tentang kebencian, yang disampaikan tokoh dalam cerita. Keraguan dan kerancuan responden dalam memastikan mana yang termasuk dalam keadaan benci yang telah disampaikan oleh tokoh. Sebagian besar responden banyak yang menjawab benar dan hanya beberapa responden saja yang menjawab salah untuk kekecewaan dan kemarahan.

Kesedihan terdapat tiga puluh tiga jawaban salah dari responden. Sembilan puluh sembilan persen menjawab salah dikarenakan mereka kurang memahami cuplikan teks novel dan mengalami kebingungan serta salah tafsir dari responden. Apakah cuplikan tersebut masuk dalam bagian dari kesedihan atau kemarahan.

Bagian dari kenikmatan atau kesenangan sendiri terdapat tiga puluh jawaban salah untuk kesenangan, empat jawaban salah untuk haru, dan delapan jawaban salah untuk kebahagiaan. Dalam hal ini dapat disimpulkan bahwa adanya kerancuan dan kebingungan responden dalam menentukan mana yang termasuk rasa senang, terharu, dan bahagia.

Rasa terkejut terdapat sebelas jawaban salah. Beberapa responden tersebut terkecoh dengan jawaban yang diberikan peneliti yaitu antara jawaban "terkejut" dan "tidak percaya". Responden kurang teliti dalam memahami cuplikan cerita dari novel tersebut, responden tidak melihat konteks kalimatnya. Sehingga argument mereka salah dalam menafsirkan cuplikan cerita novel tersebut.

Rasa ketakutan terdapat tiga puluh empat jawaban salah. Sembilan puluh sembilan persen responden menjawab salah. Mereka kurang teliti dan memahami pertanyaan dari kuesioner yang diberikan. Terdapat kerancuan dari jawaban yang disediakan. Mereka kesulitan dan merasa antara rasa bingung dan was-was itu sama. Responden belum memahami dan merasakan apa yang dirasakan tokoh dalam dialog tersebut. Dari pembahasan di atas dapat disimpulkan bahwa sebagian besar yaitu lima puluh persen responden dapat menjawab separuh dari sepuluh pertanyaan tentang emosional novel Dalam Rinai Hujan. Yang berarti 
sebagian besar responden menjawab lima soal benar, yaitu dua puluh enam responden menjawab benar soal nomor 1, tiga puluh dua responden menjawab benar soal nomor 3 , tiga puluh responden menjawab benar soal nomor 5 , tiga puluh dua responden menjawab benar soal nomor 7, dan tiga puluh responden menjawab benar soal nomor 8 . Hal ini menunjukkan bahwa tidak ada masalah untuk memahami nilai-nilai emosional dalam novel, walaupun ada sebagian responden yang kurang memahami beberapa nilai-nilai emosional.

c) Nilai-nilai Didaktis. Pendidikan

Secara etimologis berasal dari bahasa Yunani "Paedogogike", yang terdiri atas kata "Pais" yang berarti "Anak" dan kata "Ago" yang berarti "Aku membimbing". Pendidikan berarti segala usaha orang dewasa dalam pergaulannya dengan anak-anak untuk memimpin perkembangan jasmani dan rohaninya ke arah kedewasaan. Hakikat pendidikan bertujuan untuk mendewasakan anak didik, maka seorang pendidik haruslah orang yang dewasa, karena tidak mungkin dapat mendewasakan anak didik jika pendidiknya sendiri belum dewasa. Proses pendidikan bukan berarti hanya dapat dilakukan dalam satu tempat dan suatu waktu. Dihubungkan dengan eksistensi dan kehidupan manusia, nilai-nilai pendidikan diarahkan pada pembentukan pribadi manusia sebagai makhluk individu, sosial, religius, dan berbudaya.

Sebagai karya sastra, novel mengandung pesan atau nilai-nilai yang mampu mempengaruhi perilaku seseorang. Adapun nilai-nilai pendidikan yang dapat ditemukan dalam novel adalah sebagai berikut:

a) Religi

Religi merupakan suatu kesadaran yang menggejala secara mendalam dalam lubuk hati manusia sebagai human nature. Nilai-nilai religius bertujuan untuk mendidik agar manusia lebih baik menurut tuntunan agama dan selalu ingat kepada Tuhan. Nilai-nilai religius yang terkandung dalam karya seni dimaksudkan agar penikmat karya tersebut mendapatkan renungan-renungan batin dalam kehidupan yang bersumber pada nilai-nilai agama. Nilai-nilai religius dalam seni bersifat individual dan personal. Di dalam novel Dalam Rinai Hujan terdapat nilai-nilai keagamaan yang dapat dijadikan pembelajaran bagi pembacanya. Hal ini tertuang dalam cerita yang menceritakan bahwa tokoh tidak melupakan agamanya walaupun sedang dilanda masalah dan beban yang berat. Bahkan diceritakan tokoh semakin rajin beribadah dan mendekatkan diri pada Tuhannya, serta tingginya solidaritas, saling menghargai dan menghormati sesama manusia. Seperti yang telah disampaikan Meirotul Novitasari yaitu "kita harus selalu mendekatkan diri kepada Tuhan dalam keadaan apapun, agar kita diberikan jalan yang lurus, dan ditabahkan hatinya dalam menghadapi cobaan hidup". Hal ini senada dengan apa yang disampaikan 
oleh Al-Agus Slamet "dalam keadaan apapun kita sebagai manusia harus selalu mendekatkan diri pada Tuhan". Dari hasil wawancara juga didukung dengan hasil quesioner yang telah dibagikan terdapat empat jawaban salah dengan porsentase sepuluh persen. Baik tertulis maupun lisan anak usia SMP telah menangkap dan memahami pesan religi yang penulis sampaikan di cerita dalam novel.

b) Nilai Pendidikan Moral.

Merupakan makna yang terkandung dalam karya seni, yang disaratkan lewat cerita. Moral dapat dipandang sebagai tema dalam bentuk yang sederhana, tetapi tidak semua tema merupakan moral. (Kenny dalam Nurgiyantoro, 2005: 320). Hasbullah (dalam Amalia, 2010) menyatakan bahwa, moral merupakan kemampuan seseorang membedakan antara yang baik dan yang buruk. Nilai moral yang terkandung dalam karya seni bertujuan untuk mendidik manusia agar mengenal nilai-nilai etika merupakan nilai baik buruk suatu perbuatan, apa yang harus dihindari, dan apa yang harus dikerjakan, sehingga tercipta suatu tatanan hubungan manusia dalam masyarakat yang dianggap baik, serasi, dan bermanfaat bagi orang itu, masyarakat, lingkungan, dan alam sekitar.

Di dalam novel Dalam Rinai Hujan terdapat nilai-nilai moral yang dapat dicontoh dan dijadikan pelajaran oleh pembaca. Di dalam novel Dalam Rinai Hujan terdapat nilai-nilai moral baik itu sifat baik yang dapat dicontoh dan sifat buruk yang tidak patut ditiru oleh pembaca. Disini penulis menceritakan tingkah laku remaja yang masih bersekolah yang suka berkelahi, bertindak kasar, dan berkata kotor, tingkah laku yang seperti inilah yang tidak boleh ditiru dan harus dibuang dari pemikiran anak remaja saat ini. Selain sifat buruk penulis masih menyelipkan sifat-sifat baik yang dapat dijadikan contoh yaitu rasa solidaritas terhadap sesama dan kesetiakawanan terhadap teman dan sahabat.

Dari hasil questioner, peneliti memberikan tiga buah pertanyaan tentang nilai moral yang terkandung dalam novel kepada responden. Hasil menunjukkan untuk pertanyaan pertama, terdapat dua puluh empat jawaban salah, untuk pertanyaan kedua terdapat tiga puluh satu jawaban salah, dan soal ketiga terdapat dua jawaban salah. Dapat disimpulkan masih ada kerancuan dan kebingungan responden dalam menentukan pesan moral yang ada dalam novel. Namun, responden sudah cukup memahami apa saja pesan moral yang terkandung dalam novel dan pesan-pesan tersebut dapat dijadikan contoh untuk dikehidupan nyata.

c) Nilai Pendidikan Sosial.

Kata "sosial" berarti hal-hal yang berkenaan dengan masyarakat/ kepentingan umum. Nilai pendidikan sosial merupakan hikmah yang dapat diambil dari perilaku sosial dan tata cara hidup sosial. Perilaku sosial berupa sikap seseorang terhadap peristiwa yang terjadi di sekitarnya yang ada hubungannya dengan orang lain, cara berpikir, dan hubungan sosial bermasyarakat antar individu. 
Nilai pendidikan sosial mengacu pada hubungan individu dengan individu yang lain dalam sebuah masyarakat. Bagaimana seseorang harus bersikap, bagaimana cara mereka menyelesaikan masalah, dan menghadapi situasi tertentu juga termasuk dalam nilai sosial. Dalam masyarakat Indonesia yang sangat beraneka ragam coraknya, pengendalian diri adalah sesuatu yang sangat penting untuk menjaga keseimbangan masyarakat. Di dalam novel Dalam Rinai Hujan terdapat nilai-nilai yang berhubungan dengan kemasyarakatan yaitu sifat saling tolong menolong terhadap sesama. Penulis menyampaikan pesan sosialnya melalui tokoh yang diceritakan dalam novel seperti tokoh Mbog Gio yang dengan tangan terbuka menolong dan membantu Siwi yang sedang ditimpa kesusahan yang amat berat meskipun pada saat itu tokoh Mbog Gio tidak mengenal Siwi. Lalu, seperti bantuan dan dukungan yang diberikan teman-teman tokoh Widi yang sedang mencari keberadaan kakaknya. Seperti apa yang disampaikan oleh Silfia Indriani "kita harus saling membantu tanpa pandang bulu". Hal ini senada dengan jawaban Lita Nurannisya "kita harus saling membantu, tanpa memandang siapa orang yang kita bantu" dan seperti yang dikatakan oleh Al-Agus Slamet "saya harus saling membantu sesama teman". Dari hasil quesioner hanya terdapat empat jawaban salah dengan porsentase sepuluh persen. Hal ini sudah membuktikan bahwa pesan sosial yang ingin disampaikan oleh penulis dapat dipahami dan dijadikan contoh untuk di kehidupan nyata.

d) Nilai Pendidikan Budaya.

Nilai-nilai budaya menurut merupakan sesuatu yang dianggap baik dan berharga oleh suatu kelompok masyarakat atau suku bangsa yang belum tentu dipandang baik pula oleh kelompok masyarakat atau suku bangsa lain sebab nilai budaya membatasi dan memberikan karakteristik pada suatu masyarakat dan kebudayaannya. Di dalam novel Dalam Rinai Hujan terdapat nilai-nilai budaya yang masih ada sampai saat ini. Budaya tersebut adalah mandi di pancuran tengah malam hanya dengan mengenakan kain sebagai kemben dan masih menganutnya masyarakat pada falsafah hidup orang di kampong yaitu "daripada memagari rumah kita dengan tembok, lebih baik memagarinya dengan mangkok". Yang arti falsafah itu adalah bahwa mereka lebih memilih "memagari" diri dan keluarga mereka melalui keeratan tali silaturahmi yang dibangun dengan tetangga-tetangga kiri kanan.

Dari hasil quesioner yang dibagikan terdapat tiga jawaban salah tentang nilai-nilai budaya yang terdapat dalam novel tersebut. Hanya sembilan persen dari keseluruhan responden yang menjawab salah. Hal ini membuktikan bahwa resepsi anak usia SMP telah hampir memenuhi keinginan penulis dalam menyampaikan isi dan nilai-nilai yang tertulis dalam novel. 
Dari pembahasan di atas dapat disimpulkan bahwa sebagian besar yaitu lima puluh sembilan persen responden dapat menjawab separuh dari sepuluh pertanyaan tentang emosional novel Dalam Rinai Hujan. Yang berarti sebagian besar responden menjawab enam soal benar, yaitu tiga puluh dua responden menjawab benar soal nomor 3, tiga puluh empat responden menjawab benar soal nomor 4, dua puluh sembilan responden menjawab benar soal nomor 5, tiga puluh empat responden menjawab benar soal nomor 6, tiga puluh satu responden menjawab benar soal nomor 7 , dan tiga puluh responden menjawab benar soal nomor 8. Hal ini menunjukkan bahwa tidak ada masalah untuk responden dalam memahami nilai-nilai didaktis dalam novel, walaupun ada sebagian responden yang kurang memahami beberapa nilai-nilai didaktis.

\section{PENUTUP}

Dari hasil penelitian yang telah dilakukan oleh peneliti dapat disimpulkan respon dan resepsi anak usia SMP terhadap novel teenlit menunjukkan keantusiasan mereka terhadap novel tersebut. Dalam hal ini apa yang ingin disampaikan oleh penulis terhadap pembaca dapat dikatakan telah berhasil meskipun tidak seratus persen. Resepsi anak usia SMP terhadap novel ini sudah hampir mendekati apa yang ingin disampaikan oleh penulis. Responden telah menangkap dan memahami nilai-nilai apa saja yang ada di dalam novel. Berikut uraiannya, pengetahuan anak usia SMP terhadap nilai-nilai estetika yang terkandung dalam novel tersebut terlihat cukup menguasai. Hal ini terlihat dari besarnya persentase yang menunjukkan angka lima puluh dua persen dengan jawaban benar delapan soal dari total sepuluh soal. Hal ini menunjukkan bahwa besarnya pengetahuan mereka terhadap nilai-nilai estetika yang terdapat dalam novel. Meskipun demikian ada beberapa anak yang menunjukkan telah menjawab dengan jawaban benar semua yaitu sepuluh soal dengan persentase dua belas persen dan yang menjawab sembilan soal benar dengan persentase dua belas persen. Adapun dari jumlah keseluruhan responden yang menjawab tujuh soal dan enam soal benar adalah sama-sama dua belas persen. Hal ini menunjukkan bahwa pengetahuan responden terhadap nilai-nilai estetika dalam novel Dalam Rinai Hujan sebagian besar telah mengetahui dan menguasai, tidak ada lagi keraguan atau kebingungan dalam menjawab soal dari kuesioner yang telah diberikan oleh peneliti.

Berkaitan dengan nilai-nilai emosi menunjukkan hasil yang berbanding terbalik dengan hasil jawaban nilai estetika. Hal ini diperkuat dengan hasil jawaban benar lima soal sebanyak tujuh belas orang dengan persentase lima puluh persen, ini menunjukkan pengetahuan anak seusia SMP dalam memahami dan memaknai nilai-nilai yang berhubungan dengan emosi dan perasaan masih kurang. Mereka masih kurang bisa membedakan perasaan mana yang termasuk dalam amarah, kesedihan, 
kenikmatan/kesenangan, terkejut, dan ketakutan. Namun masih ada tiga belas orang yang menjawab dengan persentase tiga puluh delapan persen benar enam soal, yang berarti dalam hal ini masih ada yang menjawab benar diatas nilai minimum.

Dari hasil bagan yang telah dipaparkan, menunjukkan responden menjawab benar enam soal dengan persentase tertinggi lima puluh sembilan persen, menjawab benar tujuh soal dengan persentase tiga puluh lima persen, menjawab benar delapan soal dengan persentase enam persen. Dari hasil diatas menunjukkan bahwa responden dalam memahami dan mengetahui nilai-nilai yang terkandung dalam nilai didaktis sudah cukup bagus karena hasil menunjukkan responden menjawab diatas nilai minimum atau diatas rata-rata. Meskipun hasil telah menunjukkan hasil yang besar di jawaban benar enam soal yang tertinggi, namun masih ada responden yang menjawab benar delapan soal meskipun hanya dua orang saja, dengan demikian pemahaman anak usia SMP terhadap nilai didaktis sudah cukup bagus.

\section{Saran}

\section{(1).Kepada Guru Bahasa \& Sastra Indonesia}

Bagi guru Pend. Bahasa \& Sastra Indonesia selayaknya peneletian ini dijadikan acuan untuk meningkatkan kemampuan mengajar sastra khususnya nilai-nilai yang terkandung di dalam novel baik nilai estetika, nilai emosional, maupun nilai didaktis. Sehingga anak-anak mendapat pengetahuan dan pemahaman terhadap sastra khususnya tentang resepsi sebuah novel di sekolah mereka.

\section{(2) Kepada Peneliti Selanjutnya}

Penelitian ini masih jauh dari sempurna dan banyak memiliki kekurangan. Untuk peneliti selanjutnya yang ingin mengkaji ulang, peneliti menyarankan untuk lebih banyak membaca novel khususnya novel teenlit, serta melakukan pendekatan terhadap responden sehingga peneliti tahu batas kemampuan responden. Hasil peelitian ini dapat dikembangkan dengan melakukan penelitian lanjutan.

\section{(1) Kepada Anak Seusia SMP}

Novel merupakan karya sastra mengandung rangkaian cerita kehidupan seseorang dengan orang disekelilingnya dengan menonjolkan watak dan sifat setiap pelakunya. Diharapkan untuk anak seusia SMP dapat lebih galak membaca novel dan lebih giat memahami nilai-nilai yang ada di dalam novel. Mengingat di dalam novel terdapat nilainilai kehidupan yang dapat dicontoh dan diterapkan dalam kehidupan nyata.

\section{DAFTAR RUJUKAN}

Ali, Muhammad, asrori, Muhammad 2012, Jakarta, Bumi Aksara, Psikologi remaja 
Ibrahim, Abdul Syukur, Prof. Dr. H 2011, Tulungagung, Cahaya Abadi, Karya Sastra dan Pembaca

Nurgiyantoro, Burhan Prof. Dr. M, Pd 2010, Yokyakarta, Gajah Mada University Press, Teori Pengkajian Fiksi

Pradopo, Rachmat Djoko Prof. Dr 2013, Yogyakarta, Pustaka Pelajar, Beberapa Teori Sastra, Metode Kritik, Dan Penerapannya

Priyatni, Endah Tri, 2012 Jakarta, Bumi Aksara, Membaca Sastra Dengan Ancangan Literasi Kritis

Ratna, Nyoman Kutha, Prof. Dr 2012, Yogyakarta, Pustaka Pelajar, Teori, Metode dan Teknik dan Penelitian Sastra

Ratna, Nyoman Kutha, Prof. Dr 2011, Yogyakarta, Pustaka Pelajar, Antropologi Sastra

Sugiyono, Prof. Dr 2010, Bandung, Alfabeta, Metode Penelitian Pendidikan

http://www.jendelasastra.com/wawasan/artikel/sastra-indonesia-antara-estetika-dan-etika diakses pada tanggal 21 februari 2014

http://riungsastra.wordpress.com/2012/08/04/resepsi-sastra-teori-dan-metodepenerapannya/ di akses pada tanggal 21 februari 2014

http://www.sabda.org/pelitaku/teenlit_sebagai_cermin_budaya_remaja_perkotaan_masa_k ini diakses pada tanggal 22 februari 2014

http://eprints.uns.ac.id/2406/1/166-304-1-SM.pdf diakses pada 11 maret 2014 